\title{
Assessment of Bread Safety in Nigeria: One Decade after the Ban on the Use of Potassium Bromate
}

\author{
Emeje $\mathrm{OM}^{1 *}$, Ifiora $\mathrm{BI}^{1}$, Ezenyi $\mathrm{Cl}^{1}$ and Ofoefule $\mathrm{SI}^{2}$
}

${ }^{1}$ National Institute for Pharmaceutical Research and Development, Abuja, Nigeria

${ }^{2}$ Department of Pharmaceutical Technology and Industrial Pharmacy, University of Nigeria, Nsukka, Enugu State, Nigeria

\begin{abstract}
In 2004 the National Agency for Food, Drug Administration and Control (NAFDAC), the agency responsible for regulating drugs, foods and chemicals in Nigeria, banned the use of potassium bromate in bread on account of its deleterious effect and carcinogenicity in humans. Consequently, researchers periodically evaluate the compliance level by the industries and the results have been alarming. In the present evaluation, carried out in the Nigeria's federal capital; the seat of government, twenty-six different brands of breads were sampled from the 6 area councils. Quality assessment shows that, all the brands contained potassium bromate in a quantity that exceeded the minimum recommended by the FDA suggesting that most bread circulating in FCT are unsafe for human consumption. Two of the bread samples which were relatively safe were not even registered by NAFDAC. It is therefore concluded that, urgent steps need to be taken to prevent the looming danger of consuming carcinogenic products circulating in town before its too late.
\end{abstract}

\section{Keywords: Potassium bromate; Carbohydrate; Bread; Vitamins}

\section{Introduction}

Like most parts of the globe, bread is a very popular foodstuff in Nigeria. It is consumed extensively in homes, restaurants and hotels [1]. Although bread is made from different carbohydrate sources such as maize and rice, the most popular source is low protein wheat. Bread is made by baking, and would usually contain several other ingredients that help improve the quality of the bread. According to Vicki [2], some of the basic ingredients in bread include; flour, table salt, sugars, flavors and at least a flour improver such as potassium bromate. Potassium bromate helps to hold bread dough together, enhances its elasticity, promotes bread swelling and also makes the bread to be fluffy and soft; qualities that attract customers. As reported in our earlier study, it is generally accepted that, "the major challenge in both the flour milling industry and bakeries is the baking quality of flour", and this is determined by the capacity of the dough prepared from it to retain gas. It is usually difficult to have flours from different sources with similar or same characteristics. As a result of these wide variations in the composition of flour, makers of bread usually subject them to various treatments such as addition of supplements/conditioning agents (flour/bread improvers). These treatments give the dough strength during mixing, extensibility for molding and also increase loaf volume and texture. Over the years, several improvers have been used but studies have shown some to be deleterious to health, thereby necessitating their ban. In Nigeria for example, the use of potassium bromate in bread was banned by the country's apex drug and food regulatory agency; the National Agency for Drug Administration and Control (NAFDAC) in 2004 [3]. The fight against the use of potassium bromate was so hot to the extent that, bread makers would boldly inscribe "bromate free" on their product package. Six years into the ban of potassium bromate, we investigated the compliance level in the Eastern part of Nigeria by evaluating 23 most common breads consumed within the zone, surprisingly, all the samples analyzed contained potassium bromate above the acceptable limit. The result of our investigation in 2010 generated much interest among scientists that within three years $(2011-2013)$ of our publication, two similar studies by other researchers [4,5] have been published. Similar to our findings in 2010, these researchers discovered that, all the bread samples evaluated, had potassium bromate in concentration above safe level for human consumption.

It is exactly ten (10) years after our first report and we again went into the Nigerian market to sample all available bread; Bread samples were obtained from bakeries, fast foods joints, open markets, bus stops and hawkers within the six area councils of the federal capital territory, Abuja. It became common in bread industry to make breads that are bromate free specifically for NAFDAC tests in order to secure approval, but afterwards, bakers continue to use this banned chemical. One of the reasons attributed to the popularity and continuous use of potassium bromate among flour miller and bakers is that, it is cheap and probably the most efficient oxidizing agent. It is believed to act as a slow oxidizing agent throughout the fermentation and baking process affecting the structure and the rheological properties of the dough thereby assisting in the raising process, while at the same time producing a texture in the finished product that is appealing to the public.

Apart from the carcinogenic [6-9] effect of potassium bromate, it has also been implicated in cough and sore throat when inhaled [10], kidney failure, breakdown of the nutritional quality of bread by its ability to degrade vitamins A2, B1, B2, E and niacin which are the main vitamins available in bread [11]. This chemical has also been reported to cause abdominal pain, diarrhea, nausea, vomiting, and kidney failure, hearing loss, bronchial and ocular problems. According to a report, [11] significant differences in essential fatty acid content of flour treated with bromate or in bread made from flour containing bromate were recorded.

It is against this background that this investigation was undertaken

*Corresonding author: Emeje OM, National Institute for Pharmaceutica Research and Development, Abuja, Nigeria, Tel: +2348037035738; E-mail: martinsemeje@yahoo.com

Received November 07, 2014; Accepted November 24, 2014; Published January 07, 2015

Citation: Emeje OM, Ifiora BI, Ezenyi Cl, Ofoefule SI (2015) Assessment of Bread Safety in Nigeria: One Decade after the Ban on the Use of Potassium Bromate. J Food Process Technol 6: 409. doi:10.4172/2157-7110.1000409

Copyright: (C) 2015 Emeje OM, et al. This is an open-access article distributed under the terms of the Creative Commons Attribution License, which permits unrestricted use, distribution, and reproduction in any medium, provided the original author and source are credited. 
in the nation's capital, Abuja, Nigeria where the consumption of assorted breads is very high probably because of the city plays host to the society's well to do. This study therefore is aimed at assessing level of compliance ten years after NAFDAC's ban on the use of potassium bromate in bread as well as the safety of bread being marketed in the Nigerian market.

\section{Materials and Method}

0.1N Hydrochloric acid (Sigma chemical Co, St Louis USA), pure samples of potassium iodide and potassium bromate, (Sigma chemical Co, St Louis USA) 26 bread samples. Bread samples were obtained from bakeries, fast foods joints, open markets, bus stops and hawkers within the six area councils of the federal capital territory, Abuja.

\section{Determination of potassium bromate in bread samples}

The method reported by Emeje et al. was adopted; briefly, $1 \mathrm{~g}$ of each bread sample was weighed and transferred into a test tube, $10 \mathrm{~mL}$ of distilled water was added into each test tube, shaken vigorously and allowed standing for $20 \mathrm{~min}$ at a temp of $28 \pm 10^{\circ} \mathrm{C}, 5 \mathrm{~mL}$ of the solution was decanted into another test tube, then $5 \mathrm{~mL}$ of $0.5 \%$ prepared potassium iodide solution in $0.1 \mathrm{~N} \mathrm{HCl}$ was added to the solution. Any color change was noted. The presence of potassium bromate was indicated by change in color from light yellow to purple. The absorbance of the sample was taken at $620 \mathrm{~nm}$ in a UV-vis spectrophotometer (Shimadzu, UV 160A, Japan). Absorbance of the sample was converted to concentration with reference to Beer's calibration curve previously constructed for potassium bromate using the pure sample. Values reported here are mean of three replicate determinations. The other bread samples were similarly treated.

\section{Results and Discussion}

When potassium bromates complexes with potassium iodide, it gives a purple coloration [12]. As noted in our previous study, the color intensity is dependent on the concentration of potassium bromate in the reacting medium. In this study, a range of color reactions were observed; ranging from light purple to dark purple. Figure 1 shows the representative pictures of the bread supernatant, potassium iodide solution and the color change that occurred when the potassium iodide solution was added to the bread solutions. The essence of these pictures was to bring to enable the reader appreciate the color changes that were observed during this analysis. Table 1 shows the color identification, registration status (whether the bread had NAFDAC registration number or not) and the calculated concentration of potassium bromate based on the UV analysis of potassium bromate in the 26 bread samples. Two of the bread samples (samples W and Y) did not show any visible color change when they were treated with acidified potassium iodide solution, implying that, it may not contain any potassium bromate or that potassium bromate if present could be in residual undetectable quantities. The remaining 24 samples showed positive result for the presence of potassium bromate to varying degrees. As can be seen from the table, the least quantity of potassium bromate detected was 1.01 $\mu \mathrm{g} / \mathrm{g}$ and the highest quantity was $12.66 \mu \mathrm{g} / \mathrm{g}$. According to the Food and Drug Administration (FDA), the maximum amount of potassium bromate allowed in bread is $0.02 \mu \mathrm{g} / \mathrm{g}$. The implication of this result therefore is that, none of the bread samples is safe. This is because, the amount of potassium bromate found in each of the 26 bread samples was more than $0.02 \mu \mathrm{g} / \mathrm{g}$. Worthy of note here is the fact that, even the bread samples which did not show any visible color reaction (samples $\mathrm{W}$ and $\mathrm{Y}$ ), gave potassium bromate levels greater than $0.02 \mu \mathrm{g} / \mathrm{g}$. The UV result corroborates our earlier postulation that, undetectable levels of potassium bromate may be implicated in the absence of any discernible color reaction in samples $\mathrm{W}$ and $\mathrm{Y}$. The result of this study is consistent with those of Ojeka et al. [12] published just 2 years after the ban on the use of potassium bromate, as well as Alli and Ojo et al. published last year. Unfortunately, this result also shows that, nothing has really changed in terms of attitude of bread makers to the use of potassium bromate in Nigeria 10 years after the ban and 4 years after we brought this dangerous recalcitrant attitude of bread makers to the public. Unlike previous studies including ours of 2010, we decided to look for evidence of regulatory approval, which in Nigeria is depicted by NAFDAC registration number. Again, to our dismay, all the bread samples in this study containing above acceptable limit of potassium bromate were registered by NAFDAC.

There is a serious implication to this; it is either NAFDAC does not actually test the products before granting approval or that, once approval is given, there is no mechanism in place to monitor compliance by the industries. NAFDAC has a full-fledged department of pharmacovigilance and one would expect that, other than drugs, foods should also be constantly monitored to ensure the safety of life of the consumer. The attitude of bakers and business men who seize every opportunity to defraud does not help. It is important for them to know that, there are basically two ways by which humans get poisoned with potassium bromate; by ingestion when it is present in food such as bread and by inhalation. It is therefore, not safe for the bread consumer and the factory worker who works in a bakery where the substance is used as bread improver. The health hazards of potassium bromate have been expounded in the literature $[13,14]$. In fact, only recently, Oloyede and Sunmonu [15] also reported hepatotoxic and nephrotoxic adverse effects potassium bromate in rodents (Figure 2).

Potassium bromate is a flour improver that acts as a maturing agent. It acts principally in the late dough stage giving strength to the dough. During the preparation of the dough, a network of protein molecules linked together by disulphide bonds is formed. The strength and elasticity of the network which gives the dough its characteristic properties is best when the network comprises of long chain proteins such as gluten. Short chain peptides such as glutathione which are present as well, react with gluten molecules breaking down the dough structure. It is to prevent this structural breakdown that oxidizing agents such as potassium bromate are often added during baking [16]. According to Kent [17], in the presence of an oxidizing agent, glutathione is oxidized to glutathione disulphide and therefore cannot interfere with disulphide links of the gluten molecules. It is heart worming to note that, some researchers [18] have reported the possibility of substituting potassium bromate with ascorbic acid, it is therefore surprising that, bakers still continue to use the former inspite of its health hazards. In fact, in their study, Ayo et al. [18] proved that on an equivalent cost basis, ascorbic acid was a more effective improver even though bromate can achieve a higher loaf volume on equivalent weight basis. Even though we made this recommendation 10 years ago, in the light of the present circumstance and with the rising cases of cancer in Nigeria, we re-emphasize the need for NAFDAC to urgently set in motion mechanism to close down all bakeries still using potassium bromate and to ensure that, alternative bread improvers such as ascorbic acid replace potassium bromate.

\section{Conclusion}

The results of this study show that, all the 26 bread samples analyzed contain potassium bromate above limit. This study also brings to the fore the need for constant monitoring by the regulatory authorities in 
Citation: Emeje OM, Ifiora BI, Ezenyi Cl, Ofoefule SI (2015) Assessment of Bread Safety in Nigeria: One Decade after the Ban on the Use of Potassium Bromate. J Food Process Technol 6: 409. doi:10.4172/2157-7110.1000409
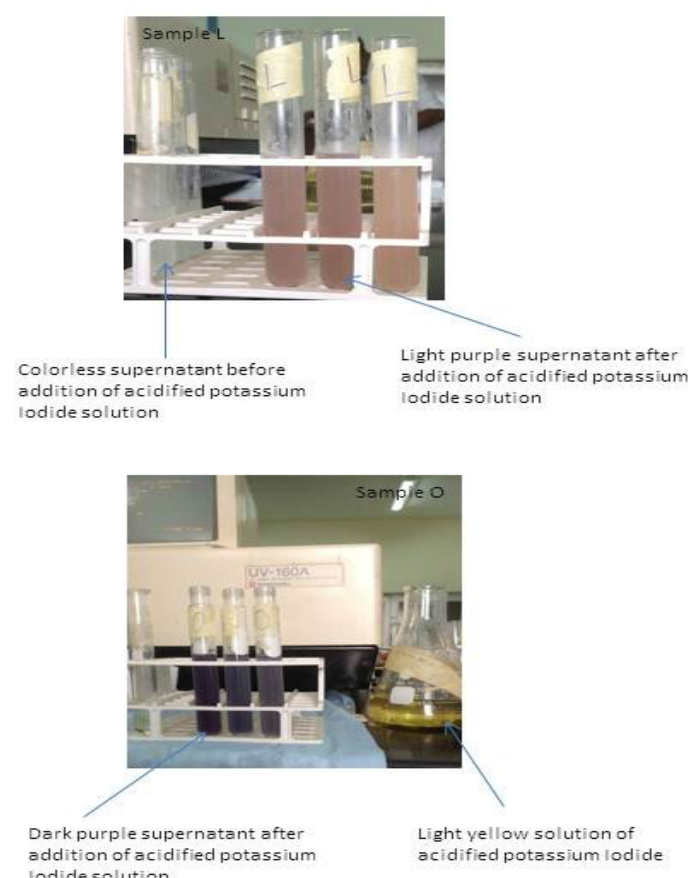
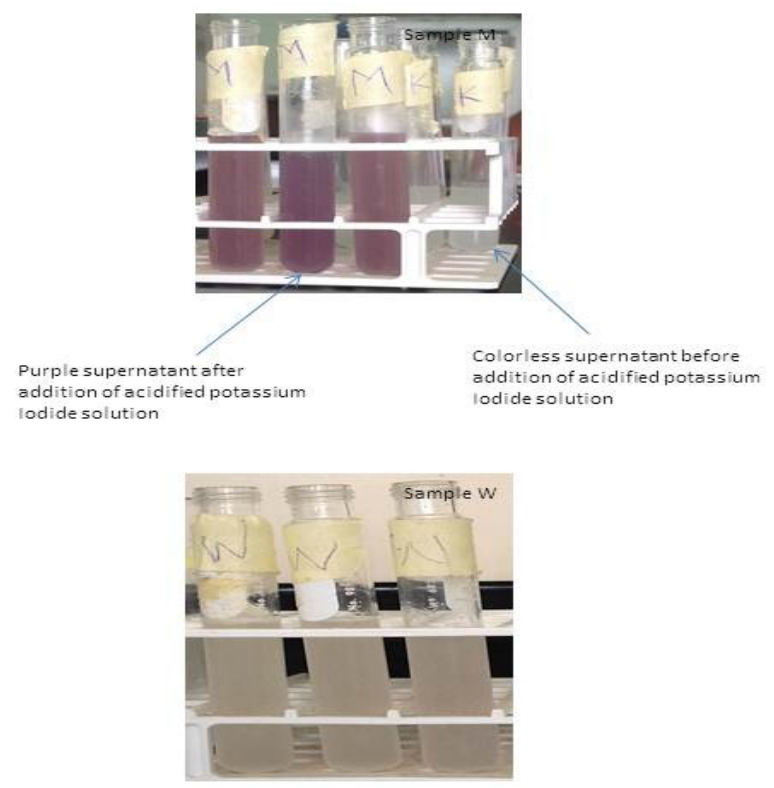

Sample W without any

discernible color change after addition of acidified potassium

Figure 1: Representative color reactions of the bread samples

\begin{tabular}{|l|c|c|c|}
\hline & Bread samples color reaction & $\begin{array}{c}\text { Regulatory } \\
\text { (NAFDAC) Status }\end{array}$ & $\begin{array}{c}\text { Quantity of potassium } \\
\text { bromate found } \mathbf{( \mu g} / \mathbf{g})\end{array}$ \\
\hline A & with potassium iodide & Nil & $2.3600 \pm 0.010$ \\
\hline B & Light Purple & Nil & $2.7600 \pm 0.031$ \\
\hline C & Light Purple & Registered & $2.7600 \pm 0.041$ \\
\hline D & Light Purple & Registered & $2.4600 \pm 0.001$ \\
\hline E & Light Purple & Registered & $4.4330 \pm 0.104$ \\
\hline F & Purple & Nil & $2.4600 \pm 0.001$ \\
\hline G & Light Purple & Registered & $4.7333 \pm 0.007$ \\
\hline H & Purple & Registered & $2.5600 \pm 0.021$ \\
\hline I & Light Purple & Registered & $3.8990 \pm 0.014$ \\
\hline J & Purple & Registered & $2.6600 \pm 0.031$ \\
\hline K & Light Purple & Registered & $2.660 \pm 0.003$ \\
\hline L & Dark Purple & Registered & $3.7600 \pm 0.010$ \\
\hline M & Light Purple & Registered & $4.3333 \pm 0.033$ \\
\hline N & Purple & Registered & $8.7770 \pm 0.003$ \\
\hline $\mathbf{O}$ & Purple & Registered & $11.3300 \pm 0.003$ \\
\hline P & Dark Purple & Registered & $2.5400 \pm 0.011$ \\
\hline $\mathbf{Q}$ & Light Purple & Registered & $3.4530 \pm 0.022$ \\
\hline R & Purple & Registered & $3.7666 \pm 0.001$ \\
\hline S & Purple & Registered & $4.3277 \pm 0.101$ \\
\hline T & Purple & Registered & $2.9333 \pm 0.004$ \\
\hline U & Purple & Nil & $2.6533 \pm 0.004$ \\
\hline V & Purple & Nil & $1.1200 \pm 0.006$ \\
\hline W & No color change & Nil & $2.4200 \pm 0.021$ \\
\hline X & Light Purple & Nil & $1.0101 \pm 0.116$ \\
\hline Y & No color change & Registered & $2.7600 \pm 0.041$ \\
\hline Z & Light purple & & \\
\hline & & & \\
\hline
\end{tabular}

Table 1: Quantitative determination of potassium bromate in some bread samples

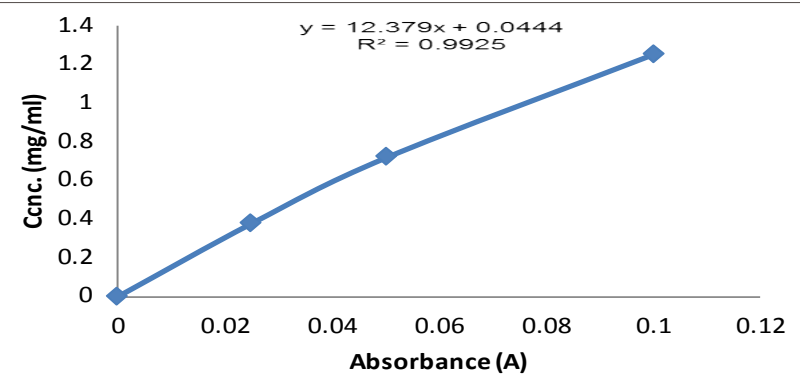

Figure 2: Calibration curve of potassium bromate using the pure sample

order to ensure that bakers always comply with rules and regulations.

\section{References}

1. Emeje MO, Ofoefule SI, Nnaji AC, Ofoefule AU, Brown SA (2009) Assessment of bread safety in Nigeria: Quantitative determination of potassium bromate and lead. African Journal of Food Science 4: 394-397.

2. Vicki S (1997) Bromate Analysis, Food Sci Technol. Bull Publications.

3. Ekop AS, Obot IB, Ikpatt EN (2008) Anti-Nutritional Factors and Potassium Bromate Content in Bread and Flour Samples in Uyo Metropolis, Nigerian. E-J Chem 5: 736-741.

4. Ojo RJ, Kajang DD, Adebayo-Gege GI, Akintayo CO (2013) Analysis of Potassium Bromate and Hydrocyanic Acid Contents of Commonly Consumed Loaves of Bread and Wheat Flour Samples In Karu, Nasarawa State, Nigeria. IOSR Journal of Environmental Science, Toxicology and Food Technology 6: $42-46$.

5. Alli LA, Nwegbu MM, Inyang BI, Nwachukwu KC, Ogedengbe JO, et al. (2013) Determination of Potassium Bromate content in Selected Bread Samples in Gwagwalada, Abuja-Nigeria. Int Health Nutr 4: 15-20.

6. Fisher N, Hutchinson JB, Berry R, Hardy J, Ginocchio AV, et al. (1979) Long 
Citation: Emeje OM, Ifiora BI, Ezenyi Cl, Ofoefule SI (2015) Assessment of Bread Safety in Nigeria: One Decade after the Ban on the Use of Potassium Bromate. J Food Process Technol 6: 409. doi:10.4172/2157-7110.1000409

term toxicity and carcinogenicity studies of the bread improver potassium bromate. 1. Studies in rats. Food Cosmet Toxicol 17: 33-39.

7. Kurokawa Y, Aoki S, Matsushima Y (1986) Dose response studies on carcinogenicity of potassium bromate in F344 rats after long term oral administration. J Natl Cancer Inst 77: 977-982.

8. Kurokawa Y, Maekawa A, Takahashi M (1990) Toxicity and carcinogenicity of potassium bromate: a new renal carcinogen. Environ Health Perspectives 87: 309-315

9. Watson Y (2000) Material safety data sheet potassium bromate, Mallinckrodt baker Inc. New Jersey.

10. Atkins DP (1993) Potassium Bromate in Bread. Index to MAFF-UK Food surveillance Information sheets.

11. International Agency for Research on Cancer (IARC) (1986) Potassium bromate. IARC Monograph Evaluating Carcinogenic Risk to Humans 40: 207220 .
12. Ojeka EO, Obidiaku ML, Enukorah C (2006) Spectrophotometric determination of bromate in bread by oxidation of dyes. Journal of Applied Science Environmental Management 10: 43-46.

13. Giesecke AG, Taillie SA (2000) Identifying factors affecting bromate residue levels in baked products: preliminary studies. Cereal Foods World 45: 111-120.

14. Diachenko GW, Warner CR (2002) Potassium bromate in bakery products: food technology, toxicological concerns, and analytical methodology. Bioactive Compounds in Foods. ACS Symp Ser 816: 218.

15. Oloyede OB, Sunmonu TO (2009) Potassium bromate content of selected bread samples in Ilorin, Central Nigeria and its effect on some enzymes of rat liver and kidney. Food Chemical Toxicology 4: 2067-2070.

16. Cogswell T (1997) The use of potassium bromate. Am Soc Bakery Eng Bull 240: 5-7.

17. Kent J (1984) Technology of cereals. (3 $3^{\text {rd }}$ Edition). Pergamon press oxford.

18. Ayo JA, Claride P, Ayanlere $O$ (2002) Ascorbic acid, an alternative to potassium bromate on the quality of bread. Nigerian Food Journal 20: 33-35. 